\title{
Effect of cooking in whey on the biological value of beans
}

\author{
Natalia Shamkova ${ }^{1 *}$, Asmaa Abdulhamid ${ }^{1}$ and Natalia Bugaets ${ }^{1}$ \\ ${ }^{1}$ Kuban State Technological University, 2, Moskovskaya st., Krasnodar, 350072, Russia
}

\begin{abstract}
Beans are an essential food and the primary protein source for many people worldwide, and there is a need to develop affordable and nutritious bean-based food products, particularly for individuals who are unable to consume animal protein due to financial or health constraints. This study aimed to investigate how cooking beans in whey can affect the biological value and the activity of protease inhibitors (TIA) of the bean puree obtained. Bean seeds were soaked in water for (5-6) hours, then cooked in the whey after discarding water. Boiled beans were then coarsely ground and followed by fine grinding after removing cooking liquid; the obtained bean puree was cooled to $20^{\circ} \mathrm{C}$. Following the same method, the control sample was prepared using water as a cooking liquid. Bean puree obtained from whey-cooking (BPCW) was compared to control (bean puree obtained from water-cooking (BPW)) in terms of trypsin inhibitor activity (TIA) and the relative biological value (RBV\%) using the test organism (Tetrahymena Pyriformis). TIA in BPCW decreased by $(6,7 \% ; 3,8 \%$ - for water soluble and salt soluble TIA respectively). RBV \% showed a significant increase ( $25 \%$ ) after treating samples with whey compared to control, demonstrating the efficacy of incorporating bean puree obtained by this method to develop highly nutritious bean-based foodstuffs for specialized and functional purposes.
\end{abstract}

\section{Introduction}

Bean seeds are known as a cheap, widespread staple food, which plays an important role in human nutrition with protein levels ranging from $21.4 \%$ to $23.6 \%$ [1]. Bean protein has an amino acid profile similar to that of animal products, with high levels of leucine, isoleucine, threonine, tryptophan, and phenylalanine [2]. However, bean protein is considered to be of low quality due to the lack of the essential amino acids methionine and cysteine, as well as the presence of some anti-nutritional factors such as protease inhibitors [3, 4]. These are substances of a protein nature that reduce the digestibility of proteins due to the formation of complexes with proteolytic enzymes [5].

Various methods are applied to suppress the function of proteolytic enzyme inhibitors, such as dehulling [6], flour grinding [7], prolonged soaking [8], heat-moisture treatment under pressure [9], extrusion [10], and enzymatic fermentation [11], etc.

These methods have some benefits and drawbacks, for example: extrusion and enzymatic fermentation are known to be expensive processes. Although boiling beans in water effectively reduces the activity of proteolytic enzyme inhibitors [12], the nutritional and biological value of the final product is significantly reduced because many water-soluble nutrients and vitamins are partially or completely leached into the cooking medium [13]. The use of acid or alkaline during cooking can reduce the activity of protease inhibitors since low or high $\mathrm{pH}$ affects enzyme activity.

For instance, cooking in sodium bicarbonate environment is shorter than cooking in water, while the activity of inhibitors of proteolytic enzymes is effectively reduced [14]; for cooking in acid mediums, aqueous solutions of lemon juice or acetic acids are usually used. However, after such heat treatment, the nutritional value and quality of the processed protein are still reduced [15].

Therefore, there is a need for a method for processing beans that reduces the concentration of proteolytic enzyme inhibitors and improves protein quality, thereby increasing the biological and nutritional value of the final bean products. Whey was proposed as a cooking medium for beans since it is a low-cost, widely available raw material that is rich in amino acids [16] that might improve the protein quality and increase its level in the final product.

Moreover, little research was conducted into the effect of using whey as an acidic medium for cooking beans, so, it was critical to shed light on this issue.

In-vivo protein digestibility of the obtained samples was determined using a test organism (Tetrahymena Pyriformis), as it is a cheap and effective method that can be available in any laboratory; the test organism needs the same amino acids as higher animals do and is capable of digesting protein [17].

The objective of this research was to test how replacing water as the cooking medium with whey affects the protein quality in bean samples in terms of the rational biological value and TIA, making them highly nutritious and affordable additives in a wide variety of foods.

\section{Materials and methods}

*Corresponding author: shamkova75@yandex.ru 
Kidney bean (Phaseolus vulgaris L.) var. "Mechta khozyaiki" zoned in the southern region of Russia was purchased from local markets in Krasnodar, Russia. Table 1 shows the nutritional value and amino acid composition of this variety's raw bean.

Table 1. The nutritional value and amino acid composition of the raw bean variety «Mechta khozyaiki»\%

\begin{tabular}{|c|c|}
\hline Indicator Name & Indicator Value \\
\hline Proteins, including: & 26,55 \\
\hline Albumins & 11,05 \\
\hline Globulins & 12,07 \\
\hline Glutelins & 3,43 \\
\hline Fats & 1,65 \\
\hline Carbohydrates, including: & 55,90 \\
\hline Dietary fiber & 3,90 \\
\hline Amino acid name & Amino acid value, $\%$ \\
\hline Threonine & 0,87 \\
\hline Valine & 1,12 \\
\hline Cystine & 0,38 \\
\hline Isoleucine & 1,03 \\
\hline Leucine & 1,74 \\
\hline Tyrosine & 0,63 \\
\hline Lysine & 1,59 \\
\hline Trptophan & 0,26 \\
\hline Histidine & 0,63 \\
\hline Alanine & 0,93 \\
\hline Arginine & 1,22 \\
\hline Aspartic acid & 2,65 \\
\hline Glycine & 0,84 \\
\hline Glu & 3,22 \\
\hline Proline & 0,98 \\
\hline Serine & 1,09 \\
\hline Methionine & 0,28 \\
\hline Phenylalanine & 1,13 \\
\hline
\end{tabular}

Acid cheese whey (Giaginsky milk factory, Russia) was used as a cooking medium for beans. The whey had a mass fraction of solids of $6 \%$, and $\mathrm{pH}=4.8$. The whey composition (\%) is given in table 2 .

The experiments were conducted at the Research Center of food and chemical technologies, Kuban State University of Technology, Russia.

\subsection{Physical treatments of bean seeds}

Physical treatments of bean seeds were included the following steps: cleaning beans from impurities, soaking them in tap water at room temperature with (seeds to water) ratio of $1: 3(\mathrm{w} / \mathrm{v})$ for 5 hours; cooking them in whey at (seeds to whey) a ratio of $1: 3(\mathrm{w} / \mathrm{v})$; coarse grinding of the cooked beans, followed by fine grinding and cooling. BPW was prepared in the same way as cooking beans were in water.
Table 2. Acid whey composition, (g/100g)

\begin{tabular}{|c|c|}
\hline Indicator name & Indicator value \\
\hline Proteins, $\mathrm{g}$ & 0,8 \\
\hline Fat, $\mathrm{g}$ & 0,2 \\
\hline Carbohydrates, $\mathrm{g}$ & 3,5 \\
\hline Organic acids, $\mathrm{g}$ & 0,7 \\
\hline Vitamins, mg: & \\
\hline Retinol & 0,02 \\
\hline Thiamine & 0,03 \\
\hline Riboflavin & 0,11 \\
\hline Folates & 1,0 \\
\hline Cobalamin & 0,29 \\
\hline Ascorbic acid & 0,5 \\
\hline Tocopherol & 0,03 \\
\hline Niacin & 0,14 \\
\hline Mineral elements, $\mathrm{mg}:$ & \\
\hline Potassium & 130,0 \\
\hline Calcium & 60,0 \\
\hline Magnesium & 8,0 \\
\hline Sodium & 42,0 \\
\hline Phosphorus & 78,0 \\
\hline Iron & 0,1 \\
\hline Calorie content, $\mathrm{kcal}$ & 20,0 \\
\hline
\end{tabular}

\subsection{Trypsin inhibitor activity (TIA)}

TIA was determined spectrophotometrically at $280 \mathrm{~nm}$ in (BPW, and BPCW) according to Northrop [18]. Hammarsten-grade casein (Russia), trypsin (Spofa, Czech Republic), and trichloroacetic acid (TCA) reagents (Russia) were used. An aqueous extract of samples was prepared and infused in distilled water or physiological solution $(\mathrm{NaCl}$ solution with a mass fraction of $0.9 \%)$ at a (solvent: sample) ratio of (10:1) for 12 hours at a temperature of $2{ }^{\circ} \mathrm{C}$ and centrifugation at $6000 \mathrm{rpm}$ for 15 minutes.

\subsubsection{The determination of water-soluble TIA}

To determine the activity of water-soluble trypsin inhibitors, control and experimental solutions were prepared. For control, $0.5 \mathrm{~cm}^{3}$ of water and $0.5 \mathrm{~cm}^{3}$ of a crystalline trypsin solution with a concentration of $(0.05$ $\mathrm{mg} / \mathrm{cm}^{3}$ ) were added to $1 \mathrm{~cm}^{3}$ of casein preheated to 35 ${ }^{\circ} \mathrm{C}$ (a solution with a mass fraction of $1 \%$ ). The mixture was shaken and incubated at a temperature of $35^{\circ} \mathrm{C}$ in a water bath for 10 minutes. Then $3 \mathrm{~cm}^{3}$ of trichloroacetic acid (TCA) with a concentration of $0.3 \mathrm{~mol} / \mathrm{dm}^{3}$ was added to the solution, in 60 minutes the precipitate was separated by centrifugation at $6000 \mathrm{rpm}$ for 15 minutes. To prepare the test solution, $0.5 \mathrm{~cm}^{3}$ of aqueous extract of the sample and $0.5 \mathrm{~cm}^{3}$ of trypsin were added to $1 \mathrm{~cm}^{3}$ of casein. The mixture was shaken, incubated in a water bath at a temperature of $35{ }^{\circ} \mathrm{C}$ for 10 minutes, $3 \mathrm{~cm}^{3}$ of TCA with a concentration of $0.3 \mathrm{~mol} / \mathrm{dm}^{3}$ were added, then the formed precipitate was separated by centrifugation in 60 minutes. 


\subsubsection{The determination of salt-soluble TIA}

To determine the activity of salt-soluble inhibitors, saline (solution with a mass fraction of $0.9 \% \mathrm{NaCl}$ ) has been used instead of distilled water. TIA has been defined as the amount of mg of pure trypsin inhibited per $1 \mathrm{~g}$ of the sample, according to the formula [19]:

$$
\text { TIA }=\frac{\left(D c-D_{o}\right) \cdot V \cdot r}{V_{1} \cdot H} \cdot \frac{c \cdot f}{D c}
$$

where

$\mathrm{D}_{\mathrm{c}}$ - optical density control;

$\mathrm{D}_{\mathrm{o}}$ - optical density experience;

$\mathrm{V}-$ total volume of aqueous extraction, $\mathrm{cm}^{3}$;

$\mathrm{r}$ - the multiplicity of additional dilution;

$\mathrm{V}_{1}$ - volume of aqueous extraction taken to determine, $\mathrm{cm}^{3}$;

$\mathrm{H}$ - weight of sample hitch, recalculated for dry matter, $\mathrm{g}$;

c - the amount of trypsin in the incubation mixture, mg.;

$f$ - active enzyme correction.

\subsection{The determination of the relative biological value}

The determination of relative biological value (RBV \%) of BPCW and BPW was carried out with the help of the test organism Tetrahymena pyriformis. This microscopic infusoria has a double cycle of digestion: acid and alkaline, and its change of reactions is similar to the pepsin and trypsin stages of digestion of higher animals and humans. Many of its enzymatic systems are adequate to the enzymatic systems of higher animals, and all essential amino acids are required for its growth [20]. The typical features of vital activity of higher animals and Tetrahymena pyriformis determined its wide application as a test organism in the study of metabolism, growth, and nutrition of animals. The rapid growth of Tetrahymena pyriformis infusoria in favorable conditions, in addition to its microscopic size, allows obtaining statistically significant data in a short time, coinciding with the experimental data of the studies conducted on higher animals. The method is based on the number of Tetrahymena pyriformis ciliates that have multiplied during a specific time under the same conditions when a standard protein (casein) and a test sample containing a certain amount of nitrogen are added to food [21].

Casein (standard protein) was ground in the homogenizer. The studied samples were diluted with water to a protein content of $3.0 \%$, then $\mathrm{pH}$ of the medium was brought to a value of $6.0-6.5$. The resulting suspension was poured by $5.0 \mathrm{~cm}^{3}$ into glass tubes with cotton-gauze plugs and pasteurized at a temperature range of $80-85{ }^{\circ} \mathrm{C}$ for $15-20$ minutes. After cooling, $0.05 \mathrm{~cm}^{3}$ of three-day Tetrahymena Pyriformis infusoria was added into the test tubes and diluted with distilled water in a ratio of 1: 9. The test tubes were thermostatically controlled at $25^{\circ} \mathrm{C}$ for three days, shaking after 3-6 hours, to improve the access of ciliates to the nutrient medium. After the end of the thermostatic process, $1.0 \mathrm{~cm}^{3}$ of fixing solution $\left(1.0 \mathrm{~cm}^{3}\right.$ of $5 \%$ iodine in $149.0 \mathrm{~cm}^{3}$ of water) was inserted into the tubes, the contents were thoroughly shaken, and the number of grown ciliates in the Goryaev counting chamber was counted. The relative biological value of the proteins (RBV \%) in the studied samples was calculated by the formula:

where:

$$
R B V \%=X_{1} \cdot 100 / X_{2}
$$

$X_{1}-$ the number of ciliates grown in the studied protein;

$\mathrm{X}_{2}$ - the number of ciliates grown on standard protein.

When processing the digital array, the following indicators were calculated:

the arithmetic mean value $\mathrm{M}$;

the standard deviation from the arithmetic mean $( \pm \sigma)$;

the error of the arithmetic mean $( \pm \mathrm{m})$;

the confidence $\mathrm{t}$ and the difference between $\mathrm{t}$ and probability $\mathrm{p}$;

the confidence interval I at the given probability level. The final significance of the indicators was established by the parameters of the confidence coefficient of the Student-Fisher $r$, taking into account the degrees of freedom. The values were considered significant at $(\mathrm{p}<$ $0.05)$

\section{Results and discussions}

\subsection{Trypsin inhibitor activity (TIA)}

The results of (TIA) determination in the processed bean products are shown in figure (2) and indicate that (TIA) the concentration was lower in BPCW by $(6.67 \%$ and $3.79 \%$ ) for water-soluble and salt-soluble TIA respectively compared to BPW. This is probably due to the partial destruction of (TIA) by hydrothermal process as a result of denaturation of these heat-sensitive proteins.

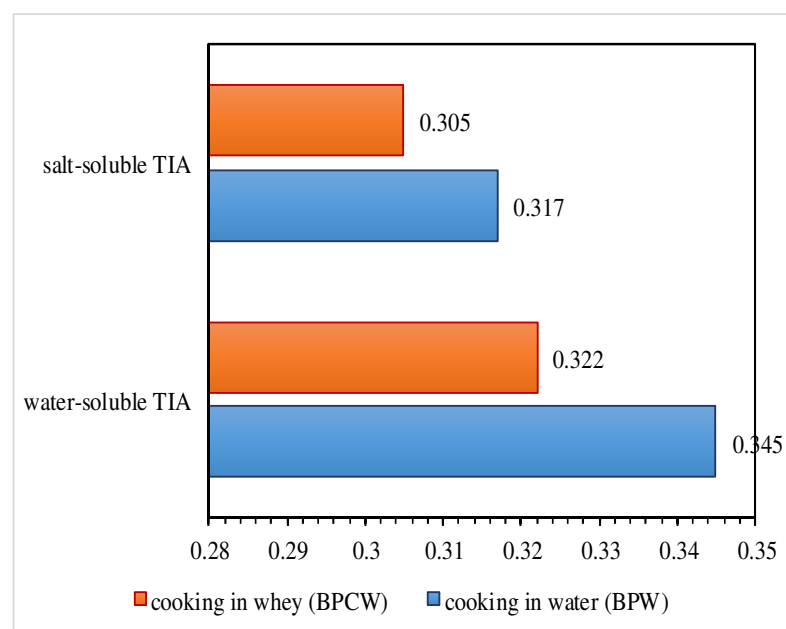

Fig. 1. Trypsin inhibitor activity (TIA) in the processed products of beans 
These results agree with those of L. Shi [22], who found that (TIA) in vegetable peas can be readily removed by ordinary and pressure cooking; similar results were reported by A. Abeykoon, who found that water boiling brought a total removal of (TIA) of cowpea, pea and kidney bean seeds [23]. The use of whey as a cooking medium was more effective in reducing (TIA) compared to water, which can be explained by whey potential to increase cell wall permeability of beans, allowing more trypsin inhibitors to diffuse into the surrounding medium.

\subsection{Relative biological value of BPW, BPCW:}

RVP\% of BPCW has exceeded that of BPW, as shown in table (6). This might be due to the fact that heat treatment induces protein denaturation, making it more susceptible to proteolysis and thus increasing the efficiency of its absorption by the infusoria and stimulating its growth, particularly in the presence of whey, which is a rich and complete source of all the essential amino acids [24] required for its growth [25].

Table 6. Relative biological value of BPW, BPCW

\begin{tabular}{|c|c|c|}
\hline $\begin{array}{c}\text { The sample } \\
\text { name }\end{array}$ & $\begin{array}{c}\text { The number of } \\
\text { infusoria, } \times 10^{4} \\
\text { per } 1 \mathrm{~cm}^{3}\end{array}$ & $\begin{array}{c}\text { Relative } \\
\text { biological value } \\
\text { to standard, }(\%)\end{array}$ \\
\hline $\begin{array}{c}\text { Casein } \\
\text { (standard) }\end{array}$ & 18 & 100 \\
\hline BPW & 6 & 33,3 \\
\hline BPCW & 8 & 44,5 \\
\hline
\end{tabular}

\section{Conclusions}

In this study, bean puree was produced by replacing water with whey as a cooking medium for beans. The processed bean product showed higher biological value, and lower activity of trypsin inhibitors than the control, demonstrating the feasibility of introducing these enriching additives into the growth of high-quality beanbased food products of plant or animal origin.

\section{References}

1. M. Nosworthy, G. Medina, A. Franczyk, J. Neufeld, P. Appah, A. Utioh, P. Frohlich, J. House. J. Nutr., 10(6), 671, (2018). https://doi.org/10.3390/nu10060671

2. R. Gundogan, A. Karaca, LWT, 130, 109609, (2020).https://doi.org/10.1016/j.lwt.2020.109609

3. W.C. Choi, T. Parr, Y.S. Lim.. J Food Sci Technol., 56(1), 281-289, (2019). https://doi.org/10.1007/s13197-018-3488-0

4. N. Kolesnikova, N. Shamkova, G. Zayko. J. Quest. of nutr., 76(3), 73-77, (2007), [In Russian].
5. N. Shamkova, A. Abdulhamid. J. Food tech., 2-3 (362-363), 38-40, (2018), [In Russian].

6. S. El-Gohery, Food Sci. Nutr., 12(4), 372-391, (2021). https://doi.org/10.4236/fns.2021.124029

7. K. Millar, E. Gallagher, R. Burke, S. McCarthy, C. Barry-Ryan. J. Food Compos. Anal., 82, 103233, https://doi.org/10.1016/j.jfca.2019.103233

8. L. Shi, K. Mu, S.D. Arntfield, M. Nickerson.. J. Food Sci. Technol., 54(4), 1014-1022, (2017). https://doi.org/10.1007/s13197-017-2519-6

9. R.Y. Khattab, S.D. Arntfield, C.M. Nyachoti. LWT-Food Sci. Technol., 42(6), 1107-1112, (2009). https://doi.org/10.1016/j.lwt.2009.02.008

10. P. Konieczka, SA. Kaczmarek, M. Hejdysz, M.Kinsner, D. Szkopek, S. Smulikowska. J. Sci. Food Agr., 100(11), 4217-4225, (2020). https://doi.org/10.1002/jsfa.10461

11. R. Coda, L. Melama, C. G. Rizzello, J. A. Curiel, J. Sibakov, U. Holopainen, N. Sozer. Int. J. Food Microbiol., 193, 34-42, (2015). https://doi.org/10.1016/j.ijfoodmicro.2014.10.012

12. O. Adeleye, S. Awodiran, A. Ajayi, T. Ogunmoyela. Heliyon, 6(11) (2020). https://doi.org/10.1016/j.heliyon.2020.e05419

13. M. Margier, S. Georgé, N. Hafnaoui, D. Remond, M. Nowicki, L. Du Chaffaut, M. Amiot, E. Reboul. J. Nutr., 10(11), 1668, (2018). https://doi.org/10.3390/nu10111668

14. E. Wanjekeche, V.Wakasa, J.G. Mureithi, Trop. Subtrop Agr., 1, 183-192, (2003).

15. S. Avilés-Gaxiola, C. Chuck-Hernández, S. Serna Saldívar. Review. J Food Sci., 83(1), 17-29, (2018). https://doi.org/10.1111/1750-3841.13985

16. D. Chartrand, M. Da Silva, P. Julien, I. Rudkowska. J. Diabetes, 41(3), 329-337, (2017). https://doi.org/10.1016/j.jcjd.2016.10.009

17. G. Rosen, W. Fernell.. Br. J. Nutr., 10(2), 156169, (1956).

18. H. Northrop, M. Kunitz, and M. Herriott. Crystalline Enzymes, (3rd ed.), (New York: Columbia University Press, 1948).

19. I. Ermakov. Biochemical methods of research of plant raw materials. (Moscow: Agropromizdat, 1987).

20. A. Ford, Br. J. Nutr. BRIT J NUTR, 14(4), 485497, (1960).

21. D. Ignatiev., Y. Shabliy. VACXNIL, 52, (1978).

22. L. Shi, K. Mu, S. Arntfield, et al. J Food Sci Technol, 54, 1014-1022, (2017). https://doi.org/10.1007/s13197-017-2519-6

23. A. Abeykoon, T. Herath, and A. Jayasinghe. A. J. Food Sci., 20(1), 1-9, (2021). https://doi.org/10.9734/afsj/2021/v20i130248

24. A. Brandelli, J. Daroit, A. Corrêa. Food Res. Int., 73, 149-161, (2015). https://doi.org/10.1016/j.foodres.2015.01.016. 
25. A. Ford.Br. J. Nutr. BRIT J NUTR, 14(4), 485497, (1960). 